\title{
Exophiala crusticola anam. nov. (affinity Herpotrichiellaceae), a novel black yeast from biological soil crusts in the Western United States
}

Correspondence Ferran Garcia-Pichel ferran@asu.edu

\author{
Scott T. Bates, † Gundlapally S. N. Reddy† and Ferran Garcia-Pichel \\ School of Life Sciences, Arizona State University, Main Campus, Tempe, AZ-85287-4501, \\ USA
}

\begin{abstract}
A novel black yeast-like fungus, Exophiala crusticola, is described based on two closely related isolates from biological soil crust (BSC) samples collected on the Colorado Plateau (Utah) and in the Great Basin desert (Oregon), USA. Their morphology places them in the anamorphic genus Exophiala, having affinities to the family Herpotrichiellaceae (Ascomycota). Phylogenetic analysis of their D1/D2 large subunit nuclear ribosomal RNA (LSU nrRNA) gene sequences suggests that they represent a distinct species. The closest known putative relative to Exophiala crusticola is Capronia coronata Samuels, isolated from decorticated wood in Westland County, New Zealand. The holotype for Exophiala crusticola anam. nov. is UAMH 10686 and the type strain is CP141 $\mathrm{b}^{\top}$ $\left(=\right.$ ATCC MYA-3639 ${ }^{\top}=$ CBS $119970^{\top}=$ DSM $16793^{\top}$ ). Dark-pigmented fungi appear to constitute an important heterotrophic component of soil crusts and Exophiala crusticola represents the first description of a dematiaceous fungus isolated from BSCs.
\end{abstract}

Biological soil crusts (BSCs) are formed by communities of micro-organisms that bind together the upper strata of soil and are common in arid lands, such as those found in the Western United States (Belnap \& Gardner, 1993). BSCs in arid lands are predominantly composed of cyanobacteria, mosses and lichens. Recent culture-dependent and independent studies have demonstrated that heterotrophic bacteria belonging to the phyla Actinobacteria, Proteobacteria and Bacteroidetes are also major components of BSCs (Smith et al., 2004; Nagy et al., 2005; Gundlapally \& Garcia-Pichel, 2006) and an effort has been made to culture and report on isolates from BSCs that are members of these phyla (Reddy \& Garcia-Pichel, 2005; Reddy et al., 2006). Although fungi have been identified as components of BSCs (Belnap et al., 2001; Fletcher \& Martin, 1948; Garcia-Pichel, 2002; Galun \& Garty, 2001), few studies (e.g. Grishkan et al., 2006; States \& Christensen, 2001) have investigated the fungal constituents

†These authors contributed equally to this work.

Abbreviations: BSC, biological soil crust; EPS, extracellular polysaccharides; LSU, large subunit; nrRNA, nuclear ribosomal RNA.

The GenBank/EMBL/DDBJ accession numbers for the D1/D2 large subunit nuclear ribosomal RNA gene sequences of strains CP141 $\mathrm{b}^{\top}$ and OR302-3 are AM048755 and D0777875, respectively. The accession number for the sequence of the internal transcribed spacer of the nuclear ribosomal RNA gene for strain $\mathrm{CP} 141 \mathrm{~b}^{\top}$ is $\mathrm{AM0} 48756$.

Comparisons of the nucleotide sequences of the D1/D2 large subunit nuclear ribosomal RNA gene of Exophiala crusticola and related taxa, details of the characteristics that distinguish strains CP $141 \mathrm{~b}^{\top}$ and OR302-3 and an additional phylogenetic tree are available as supplementary material in IJSEM Online. of BSCs or the contributions that they make to crust ecology. Here, two black yeast-like fungal strains $\left(\mathrm{CP} 141 \mathrm{~b}^{\mathrm{T}}\right.$ and OR302-3) isolated from BSCs are described as a novel species of the genus Exophiala within the family Herpotrichiellaceae.

Members of the family Herpotrichiellaceae exhibit a diverse polymorphic life cycle and, therefore, can be difficult to identify by morphology alone. However, the use of nuclear ribosomal RNA (nrRNA) gene sequence data has facilitated identification and classification of these organisms (see Spatafora et al., 1995; Untereiner \& Naveau, 1999; de Hoog et al., 2003). The family is represented by the teleomorph genus Capronia and the anamorphic genera Cladophialophora, Exophiala, Fonsecaea, Phaeococcomyces, Phialophora, Ramichloridium and Rhinocladiella (Untereiner \& Naveau, 1999). These fungi, commonly called black yeasts, are characterized by the presence of melanin or melanin-like pigments in the cell walls and by a yeast-like growth during part of their life cycles (Haase et al., 1999). Exophiala is also characterized by an annellidic form of blastic conidiogenesis and by conidiogenous cells that are often inconspicuously annellate (de Hoog \& Hermanides-Nijhof, 1977). The Dictionary of Fungi (Kirk etal., 2001) cites twelve species in the genus Exophiala; however, additional species have been described more recently (e.g. de Hoog et al., 2003). Some species of the genus Exophiala are known as occasional opportunistic human pathogens (de Hoog et al., 2003; Haase et al., 1999).

Capronia coronata Samuels, having an Exophiala anamorph and isolated from decorticated wood in the Westland 
County of New Zealand (Müller et al., 1987), was the closest known relative of the BSC isolates CP141b ${ }^{\mathrm{T}}$ and OR302-3. However, the sequence divergence value of $3 \cdot 3 \%$ in the divergent D1/D2 domain of the large-subunit (LSU) nrRNA gene indicates that our isolates belong to a distinct species and refute an anamorph-teleomorph connection (Kurtzman \& Robnett, 1998; Peterson \& Kurtzman, 1991). The International Code of Botanical Nomenclature currently allows the use of a separate binary name for the fungal anamorph if the teleomorphic relationship is not firmly established (Greuter et al., 2000); therefore, we propose the name Exophila crusticola for this novel anamorphic species.

\section{Fungus isolation and characterization}

Strains CP141b ${ }^{\mathrm{T}}$ and OR302-3 were isolated from BSC samples collected from the Colorado Plateau ( $38^{\circ} 34^{\prime} 09 \cdot 84^{\prime \prime}$ $\left.\mathrm{N} 109^{\circ} 31^{\prime} 04 \cdot 51^{\prime \prime} \mathrm{W}\right)$ and the Great Basin desert $\left(44^{\circ} 29^{\prime}\right.$ $\left.06 \cdot 03^{\prime \prime} \mathrm{N} 121^{\circ} 04^{\prime} 07 \cdot 30^{\prime \prime} \mathrm{W}\right)$, USA. Initially, $0 \cdot 5 \mathrm{~g}$ crust samples were suspended in Ringer's solution (Lorch et al., 1995), shaken for $30 \mathrm{~min}$ and the suspension was allowed to settle. Subsequently, $100 \mu$ l supernatant was placed on plates of BG11 minimal medium (Rippka et al., 1979). The plates were incubated under light at room temperature. Fungal colonies were observed on plates where cyanobacteria were also present. Strains CP141b ${ }^{\mathrm{T}}$ and OR302-3 were selected because of their dark pigmentation and replated on a nutrient-rich $10 \times$ PGY-BG11 medium (Lorch et al., 1995). This medium was also used to obtain inoculum for all biochemical tests.

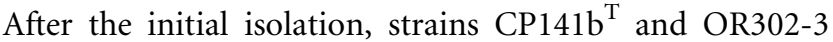
were cultured on standard PDA (Yarrow, 1998) and PGY (Lorch et al., 1995) plates, in addition to $10 \times$ PGY-BG11 plates, in order to observe growth and the formation of hyphal elements. The temperature range for growth was determined on $10 \times$ PGY-BG11 between $10-50{ }^{\circ} \mathrm{C}$ (in increments of $5^{\circ} \mathrm{C}$ ). The $\mathrm{pH}$ range for growth was determined on $10 \times$ PGY-BG11 buffered in $0 \cdot 1 \mathrm{M}$ phosphate with the $\mathrm{pH}$ ranging from 5 to 12 at intervals of $1 \mathrm{pH}$ unit. Catalase activity was determined by bubble production in $30 \%(\mathrm{v} / \mathrm{v})$ aqueous hydrogen peroxide solution. Oxidase activity was tested by the oxidation of $1 \% \quad(\mathrm{w} / \mathrm{v})$ tetramethyl- $p$-phenylenediamine (Merck). Carbon assimilation tests were performed by adding each carbon compound at a final concentration of $0.5 \%$ to a base stock of BG11 medium without citric acid (Reddy \& GarciaPichel, 2005).

Standard methodologies were followed for the maintenance of cultures and the description of yeast-like morphology (Yarrow, 1998). Micromorphological data were gathered using a conventional bright-field microscope (BH2; Olympus) or a microscope in differential interference contrast or bright-field mode (Axio Imager. A1; Zeiss). Microscopic examinations were made from fresh cells in water mounts. Measurements were made at a magnification of $\times 1000$ using a calibrated ocular. Cell and conidia dimension statistics include: $x$, the arithmetic mean of the cell/conidia length by cell/conidia width ( $\pm \mathrm{SD}$ ) for $n$ cells/ conidia measured; $\mathrm{Q}$, the quotient of cell/conidia length and cell/conidia width in any one cell/conidium, indicated as the range of variation in $n$ cells/conidia measured; Qm the mean of Q values. Colour descriptions adhere to the nomenclature and codification system outlined in the Methuen Handbook of Colour (Kornerup \& Wanscher, 1967).

\section{DNA isolation, PCR and sequence analysis}

A rapid mini-DNA isolation method from yeast-like cells was standardized as follows: a $1 \mathrm{ml}$ suspension of CP141b ${ }^{\mathrm{T}}$ culture was centrifuged in an Eppendorf tube at 10000 r.p.m. for $5 \mathrm{~min}$ at room temperature. The cell pellet was suspended in $200 \mu$ lysis buffer $(10 \mathrm{mM}$ Tris, $1 \mathrm{mM}$ EDTA pH 8, $1 \%$ SDS), $200 \mu$ Tris-saturated phenol was added and the mixture was incubated at $65^{\circ} \mathrm{C}$ for $60 \mathrm{~min}$. The suspension was then centrifuged at 10000 r.p.m. for $5 \mathrm{~min}$ at room temperature and the supernatant collected. The supernatant was treated with $200 \mu \mathrm{l}$ chloroform/iso-amyl alcohol mixture (24:1), vortexed and centrifuged at 10000 r.p.m. for $5 \mathrm{~min}$ at room temperature. The supernatant was collected and added to $20 \mu \mathrm{l} 3 \mathrm{M}$ sodium acetate and $600 \mu \mathrm{l}$ ice-cold alcohol. This mixture was vortexed and incubated at $-80{ }^{\circ} \mathrm{C}$ for $30 \mathrm{~min}$. The suspension was centrifuged at 10000 r.p.m. for $20 \mathrm{~min}$ at $4{ }^{\circ} \mathrm{C}$. The resultant DNA pellet was washed with $70 \%$ alcohol, vacuum-dried and dissolved in $20 \mu \mathrm{l}$ TE buffer.

The divergent D1/D2 domain was amplified with the combination of the NL-1 (5'-GCATATCAATAAGCGGAGGAAAAG-3') and NL-4 (5'-GGTCCGTGTTTCAAGACGG-3') primers of O'Donnell (1993). The ITS4 (5' -TCCTCCGCTTATTGATATGC-3') and ITS5 (5' -GGAAGTAAAAGTCGTAACAAGG-3') primers of White et al. (1990) were used to amplify the internal transcribed spacer (ITS1) of the nrRNA gene. PCR was performed with a final reaction mixture $(50 \mu \mathrm{l})$ containing $\sim 50$ ng genomic DNA, 25 pmol each primer, $200 \mathrm{mM}$ dNTPs, $2 \cdot 5 \mathrm{mM} \mathrm{MgCl}_{2}$, $2 \cdot 0 \mathrm{U}$ Taq polymerase and $5 \mu \mathrm{l} 10 \times$ reaction buffer (Takara). The amplification reactions were performed in a PTC 150 Mini Cycler (MJ Research) with the following cycling parameters; $5 \mathrm{~min}$ at $94^{\circ} \mathrm{C}$, followed by 30 cycles at $30 \mathrm{~s}$ at $94{ }^{\circ} \mathrm{C}, 30 \mathrm{~s}$ at $55^{\circ} \mathrm{C}$ and $60 \mathrm{~s}$ at $72{ }^{\circ} \mathrm{C}$, with a final extension for $5 \mathrm{~min}$ at $72{ }^{\circ} \mathrm{C}$. The amplified products were separated on a $1.0 \%$ agarose gel and visualized by staining with ethidium bromide $\left(0.5 \mu \mathrm{g} \mathrm{ml}^{-1}\right)$. Amplicons were removed from the gel and purified using a gel extraction kit (Qiagen). Direct sequencing of purified PCR products was performed with the ABI Big Dye Terminator kit (Perkin Elmer Applied Biosystems). Both strands of the PCR product were sequenced for the D1/D2 domain and ITS1 using the NL1 and NL4 and ITS4 and ITS5 primers, respectively.

A sequence similarity search was performed using GenBank BLASTN (Altschul et al., 1997) and sequences of closely related taxa were retrieved and aligned using the CLUSTAL W module in the MEGA 3 software package (Kumar et al., 2004). 
Pair-wise evolutionary distances between the sequences were calculated using Kimura's two-parameter model (Kimura, 1980). Phylogenetic trees were constructed using three tree-making algorithms: neighbour-joining (NJ), maximum-parsimony (MP) and the unweighted pair group method with arithmetic mean (UPGMA) in the MEGA 3 software package (Kumar et al., 2004). Clade stability in the phylogenetic trees was assessed using 1000 replicate datasets in a bootstrap analysis.

\section{Classification, phylogenetic analyses and ecology}

Strains CP141b ${ }^{\mathrm{T}}$ and OR302-3 exhibited similar growth and morphological characteristics. Nearly all physiological characteristics exhibited by these isolates were identical; however, a few minor differences were observed (see Supplementary Table S1 in IJSEM online). Sequence data for the D1/D2 domain suggests that the strains are conspecific as the domain contained only one nucleotide substitution (see Supplementary Table S2 in IJSEM online), thus having less than $1 \%$ sequence divergence (Peterson \& Kurtzman, 1991). Strain $\mathrm{CP}_{141 \mathrm{~b}^{\mathrm{T}}}$ was chosen as the representative strain for further characterization and as the basis for the species description as it was the first to be isolated.

Specific characteristics (morphological, growth-related and biochemical) of Exophiala crusticola anam. nov. are given in the species description. In general, the isolates were metabolically versatile in their use of sugars and smallmolecular mass organics, with the exception of amino acids, and were not very proficient at metabolizing complex organics. This may indicate that their ecological role may be as osmotrophs specialized on the photosynthetic exudates from cyanobacteria. Recurrent wetting and drying cycles in soil crusts promote a chronic leaching of organics from these primary producers, creating a significant concentration of dissolved organics in the soil solution, which are then available to consumers such as E. crusticola. Both isolates were recovered from minimal media on which cyanobacteria were growing and they appeared to be thriving on cyanobacterial exudates. This type of trophic role was alluded to by de Hoog (1993) who described black yeasts of the family Herpotrichiellaceae as secondary saprophytes that are known to inhabit 'bacterial mats'.

Strains CP141b ${ }^{\mathrm{T}}$ and OR302-3 exhibit morphological characters, including a dimorphic habit and inconspicuously annellate conidiogenous cells, which support their placement within the genus Exophiala. Morphologically, E. crusticola is characterized by mucoid colonies that exhibit very slow growth. Conidiogenous cells are produced on torulose hyphae, normally terminal, and on unswollen hyphae, normally as singular, intercalary, fertile loci. Conidia are globose, subglobose to ovoid (Fig. 1). The ability of E. crusticola to produce submerged hyphae that, in turn, produce conidia (Fig. 1) is not common within the genus Exophiala and may reflect a growth habit that is
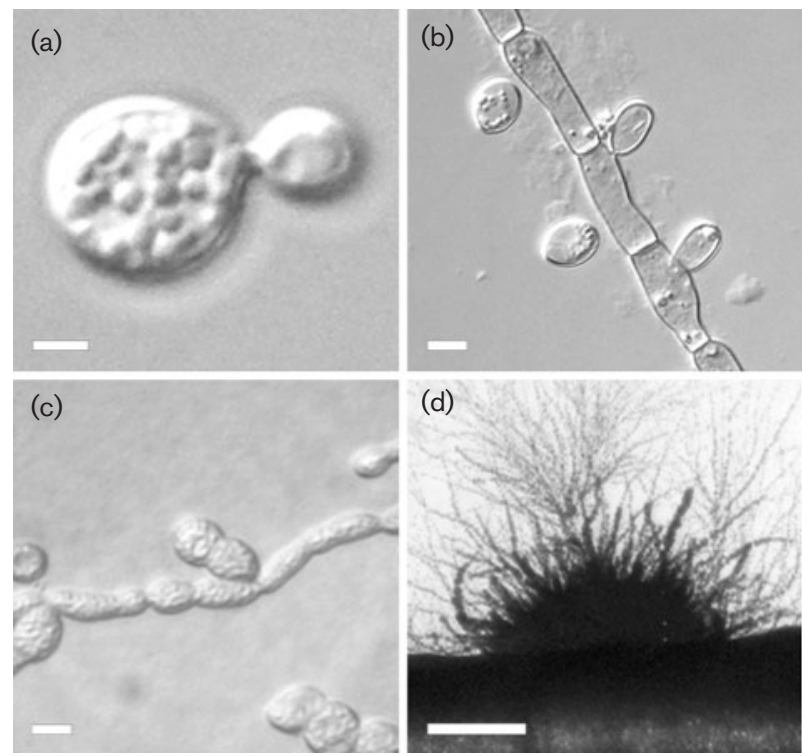

(d)

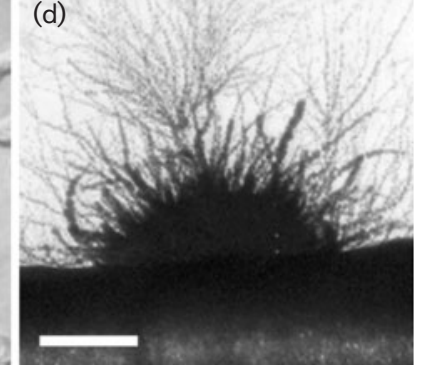

Fig. 1. Exophiala crusticola anam. nov. $C P 141 b^{\top}$ on PDA agar at $25^{\circ} \mathrm{C}$. (a) Annellate yeast-like cell; (b) conidiogenous cells producing conidia; (c) torulose hyphae; (d) fascicle of submerged hyphae protruding from colony margin. Bars, $1 \mu \mathrm{m}(\mathrm{a})$, $2 \mu \mathrm{m}(\mathrm{b}-\mathrm{c}), 1 \mathrm{~mm}$ (d).

compatible with the BSC habitat. The manner in which $E$. crusticola produces conidia is similar to that found in Exophiala lecanii-corni (Benedek \& G. Specht) Haase \& de Hoog. E. lecanii-corni, however, tends to be more conspicuously hyphal, whereas E. crusticola exhibits a more consistent yeast-like phase. In addition, the former produces ellipsoidal to reniform conidia that are narrower $(1 \cdot 5-2 \cdot 4 \mu \mathrm{m}$ in width) and have a broader range of lengths $(3 \cdot 3-5 \cdot 9 \mu \mathrm{m})$ than conidia found in E. crusticola (de Hoog \& Hermanides-Nijhof, 1977). Other species of the genus Exophiala are more readily distinguished from E. crusticola. For example, the elongated, lateral conidiogenous cells found in species such as Exophiala salmonis and Exophiala jeanselmei var. jeanselmei are lacking in E. crusticola.

Phylogenetic studies based on nrRNA gene sequences suggest that the family Herpotrichiellaceae constitutes a monophyletic entity (Untereiner \& Naveau, 1999). Our analysis included sequence data from seven taxa representing the teleomorph genus Capronia and twelve taxa representing the anamorphic genera Cladophialophora, Exophiala, Fonsecaea and Phialophora, which were extracted from GenBank. Phaeococcomyces catenatus (Chaetothyriales, Ascomycetes, Ascomycota) and Saccharomyces cerevisiae strain S288C (Saccharomycetales, Saccharomycetes, Ascomycota) were selected for the outgroup. Alignment of the D1/D2 LSU nrRNA gene sequences revealed 40 unique nucleotide signatures for E. crusticola in comparison with other closely related anamorphic (E. jeanselmei, Exophiala moniliae and Exophiala spinifera) and teleomorphic (Capronia acutiseta and Capronia coronata) taxa 
(see Supplementary Table S2 in IJSEM online). Neighbourjoining and maximum-parsimony analyses (data not shown) placed E. crusticola deep within the Herpotrichiellaceae clade. Both C. acutiseta and C. coronata showed a $3 \cdot 3 \%$ sequence divergence from E. crusticola. Although analysis using UPGMA, maximum-parsimony (data not shown) and neighbour-joining (Fig. 2) criteria revealed the close relationship between $C$. coronata and $E$. crusticola, the nodes were not strongly supported by bootstrap values. However, the analyses overwhelmingly supported this relationship over that of $C$. acutiseta with $E$. crusticola. When compared with E. crusticola, the sequence of $E$. jeanselmei showed a $3 \cdot 8 \%$ sequence divergence and those of E. moniliae and E. spinifera showed a $4.0 \%$ sequence divergence. The topology of trees recovered in a phylogenetic analysis using the ITS sequence (see Supplementary Fig. S1 in IJSEM online) also supported these conclusions. Our results reinforce other studies that have suggested the polyphyletic nature of the genera Capronia and Exophiala (e.g. Spatafora et al., 1995; Untereiner \& Naveau, 1999; de Hoog et al., 2003).

Isolation of strains of E. crusticola from Colorado Plateau and Great Basin desert BSCs samples suggests that this anamorphic fungus may be common in BSCs and that it plays a role in crust ecology. Cultivation-independent studies of field samples would be necessary to reinforce this conclusion. However, these results certainly support States and Christensen's (2001) conclusion, based on cultivation, that dark-pigmented fungi are prominent components of BSCs. Furthermore, finding E. crusticola associated with BSCs in desert localities is not surprising considering that black yeasts have been isolated from extreme environments and they are known to be able to survive severe drought, excessive temperatures and UV irradiation because of their robust, melanized cell walls (de Hoog, 1993). Extracellular polysaccharides (EPS) produced by prokaryotic organisms are known to bind soil particles, thus aiding in the establishment of BSCs and slowing erosion in desert soils (Garcia-Pichel et al., 2001). Black yeasts are also known to produce EPS (de Hoog, 1993) and, in culture when supplied with plenty of organics, isolates of E. crusticola produce copious amounts of EPS. This suggests that eukaryotic fungal organisms associated with BSCs may also contribute to soil stability in desert systems through EPS production in addition to the aggregation of soil particles by hyphae. The isolation of other EPS-producing yeasts from BSCs, such as Rhodotorula (R. Potrafka, personal communication), lends further credence to this hypothesis.

Although other unidentified 'yeasts' have been isolated from BSCs (States \& Christensen, 2001), this publication appears to be the first to clearly identify a BSC-associated black yeast. The fact that our isolates represent a novel anamorphic species underscores the need for further investigation into the diversity and ecology of fungal components of BSCs. Overall, the paucity of literature related to fungi associated with BSCs reflects the fact that these organisms are inadequately known and indicates that the field is ripe for future investigation.

\section{Latin diagnosis of Exophiala crusticola Bates, Gundlapally \& Garcia-Pichel anam. nov.}

Coloniae ex $\mathrm{CP} 141 \mathrm{~b}^{\mathrm{T}}$ in $P G Y$ ad $25^{\circ} \mathrm{C}\left( \pm 2{ }^{\circ} \mathrm{C}\right)$ tardae crescentes, $2 \cdot 0-3 \cdot 0 \mathrm{~mm}$ diametro ad 14 dies attingentes. In PDA ad $25^{\circ} \mathrm{C}\left( \pm 2{ }^{\circ} \mathrm{C}\right)$ tardae crescentes, $0.5-1.0 \mathrm{~mm}$ diametro ad 14 dies ad $25^{\circ} \mathrm{C}\left( \pm 2{ }^{\circ} \mathrm{C}\right)$ attingentes. Videor mucosae quam primum, deinde laeves ut verruculosae, siccae et firmae, elevatae ex agarum usque $1 \mathrm{~mm}$ ad limites brunneae (6E4), fusco-brunneae (6F4) ut griseo-brunneae (6F3), partes interiores nigellae. Margo integer et quam primum acutus designo, inde hyphae submersae lineares vel

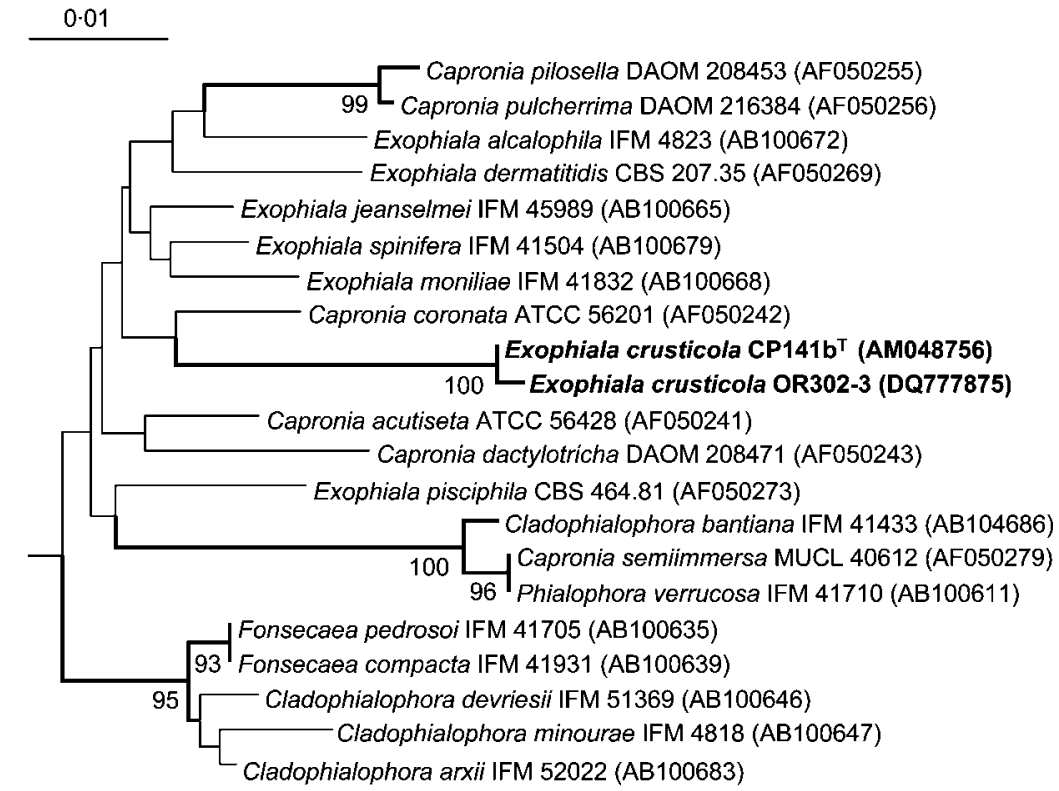

Fig. 2. Neighbour-joining tree based on the analysis of the sequence of the D1/D2 domain of the LSU nrRNA gene (approximately 540 bases) showing the relationship between Exophiala crusticola anam. nov. CP141 $\mathrm{b}^{\top}$ and related taxa. GenBank accession numbers are given in parentheses. Bootstrap values are expressed as percentages of 1000 replications and clades supported by bootstrap values over $65 \%$ are indicated (branches in bold). The outgroup, Phaeococcomyces catenatus strain CBS 650.76 (AF050277) and Saccharomyces cerevisiae strain S288C (NC001144), was trimmed from the figure without modifying the tree topology. Bar, 0.01 substitutions per nucleotide position. 
ramificantes gradatim crescentes, emergentes ut punctae fortuitae secus marginem et fasciculae abundente crescentes post 14 dies in PDA. Hyphae aeriae deinde crescentes super superficiares ex coloniae. Hyphae cellulae deficiens post 14 dies in PGY. Exsudatum et ordoratus deficiens. Ad temperatura extensa ab $5-30{ }^{\circ} \mathrm{C}$ crescens, ad vel supra $37^{\circ} \mathrm{C}$ moriens.

Cellulae fermentiformis commune, cellulae-singulae, parietes-latae, globosae, subglobosae, ovoideae ut limoniformes, $5 \cdot 6-8 \cdot 0 \times 4 \cdot 8-7 \cdot 2 \mu \mathrm{m}[\mathrm{x}=6 \cdot 5 \pm 0 \cdot 7 \times 5 \cdot 9 \pm 0 \cdot 9 \mu \mathrm{m}$, $\mathrm{Qm}=1 \cdot 1, n=20$ ], subhylinae, olivaceae pallidae ut brunneae pallidae, ad apex expediciones conidia secundariae ex singulae, minutae, inconspicuus annelatus clavae conidiiferitae. Hyphae exinflatae vel torulosae, parietes-latae, septatae, subglobosae, ovoideae, ellipsoideae ut cylindricae et elongatae, ramorae interdum vel regularae, $3 \cdot 0-8 \cdot 0 \mu \mathrm{m}$ diámetro, subhylinae, olivaceae pallidae ut brunneae pallidae; cellulae conidiagenitae non disimiles, parietes-latae, ellipsoideae ut cylindricae et elongatae, subhylinae, olivaceae pallidae ut brunneae pallidae, ramorae raro vel interdum; conidia gentiae ex minutae, inconspicuus annelatus clavae conidiiferitae, terminales ex hyphae torulosae vel laterales ex singulae, intercalares loci ex hyphae exinflatae (raro terminales). Conidia cellulae-singulae, parietes-teniae, laeves, globosae, subglobosae ut ovoideae, $4 \cdot 0-4 \cdot 8 \times 3 \cdot 2-4 \cdot 0 \mu \mathrm{m}[\mathrm{x}=4 \cdot 3 \pm 0 \cdot 4 \times 3 \cdot 5 \pm 0 \cdot 4 \mu \mathrm{m}$, $\mathrm{Qm}=1 \cdot 2, n=20]$, subhylinae, olivaceus pallidus ut brunneus pallidus. Teleomorphus incognitus.

$\mathrm{CP}_{141 \mathrm{~b}^{\mathrm{T}}}$ erat positivus pro catalasa, oxidasa, ureasa et infitialis pro lipasa, phosphatasa, gelatinasa, ADNasa, $\beta$ galactosidasa, deaminasa phenylalaninum, dihydrolasa argininae, decarboxylasa lysinae et decarboxylasa ornithinae; non poterat utor caseinum vel aesculinum. Fungo poterat utor salis acetii, arabinosum, fructosum, galactosum, glucosum, glycerinum, inulinum, acidum lacticum, lactosum, levulosum, maltosum, mannitol, rafinosum, saccharosum, sucrosum, et xylosum per origo ex carbonis, autem non poterat utor acidum citricum, dextrinum, ethanolaminum, vel acidum succinicum. Cycloheximidum cellularum ex $\mathrm{CP} 141 \mathrm{~b}^{\mathrm{T}}$ venenum est.

Holotypus: Colorado Plateau $\left(38^{\circ} 34^{\prime} 09 \cdot 84^{\prime \prime} \mathrm{N} 109^{\circ} 31^{\prime}\right.$ $\left.04 \cdot 51^{\prime \prime} \mathrm{W}\right)$, USA - segregatus ex collectio crustae biologicae terrarum. Cultura sicca ex Exophiala crusticola (isolatus typus $\left.\mathrm{CP} 141 \mathrm{~b}^{\mathrm{T}}\right)$ ad $\mathrm{UAMH}$ cum numerus accessionem 10686 deposita est. Isolatus typus $\mathrm{CP}_{141 \mathrm{~b}^{\mathrm{T}}}$ (=ATCC MYA$3639^{\mathrm{T}}=\mathrm{CBS} 119970^{\mathrm{T}}=$ DSM $16793^{\mathrm{T}}$ ) modus lyophylizatus conservatus est.

\section{Description of Exophiala crusticola Bates, Gundlapally \& Garcia-Pichel anam. nov.}

Exophiala crusticola (crus.ti'co.la. L. n. crusta crust; L. suff. - cola from L. n. incola an inhabitant; N.L. n. crusticola a crust inhabitant).

Colonies of $\mathrm{CP} 141 \mathrm{~b}^{\mathrm{T}}$ on PGY at $25^{\circ} \mathrm{C}\left( \pm 2{ }^{\circ} \mathrm{C}\right)$ are slowgrowing, attaining $2 \cdot 0-3 \cdot 0 \mathrm{~mm}$ diameter at $14 \mathrm{~d}$. On PDA at $25^{\circ} \mathrm{C}\left( \pm 2{ }^{\circ} \mathrm{C}\right)$, colonies are slow-growing, attaining
0.5-1.0 mm diameter at $14 \mathrm{~d}$. Appear mucoid at first, soon becoming smooth to verruculose, dry and firm, elevated from media up to $1 \mathrm{~mm}$, outer part brown (6E4), dark brown (6F4) to greyish brown $(6 \mathrm{~F} 3)$ and inner parts blackish. Margin entire and, at first, sharply defined, then submerged linear or branching hyphae gradually develop that emerge randomly around the margin and form abundant fascicles after $14 \mathrm{~d}$ on PDA. Aerial hyphae eventually develop over the surface of the colony. Hyphae lacking after $14 \mathrm{~d}$ on PGY. Lacking exudates and odour. Growth observed at temperatures ranging from $5-30{ }^{\circ} \mathrm{C}$, growth not observed at or above $37^{\circ} \mathrm{C}$.

Yeast-like cells are abundant, single-celled, thick-walled, globose, subglobose, ovoid to lemon-shaped, 5.6-8.0 $\times$ $4 \cdot 8-7 \cdot 2 \mu \mathrm{m} \quad[\mathrm{x}=6.5 \pm 0.7 \times 5 \cdot 9 \pm 0.9 \mu \mathrm{m}, \quad \mathrm{Qm}=1 \cdot 1$, $n=20]$, subhyaline, pale olivaceous to pale brown, developing secondary conidia at the apex from a single, minute, inconspicuously annelate conidiiferous peg. Hyphae unswollen or torulose, thick-walled, septate, subglobose, ovoid, elliptical to cylindrical and elongate, occasionally or regularly branched, $3 \cdot 0-8 \cdot 0 \mu \mathrm{m}$ in diameter, subhyaline, pale olivaceous to pale brown; conidiogenous cells undifferentiated, thin-walled, elliptical to cylindrical and elongate, subhyaline, pale olivaceous to pale brown, rarely to occasionally branched; conidia produced from a minute, inconspicuously annelate conidiiferous peg, terminally on torulose hyphae or laterally as single, intercalary loci on unswollen hyphae (rarely terminally). Conidia single-celled, thin-walled, smooth, globose, subglobose to ovoid, $4 \cdot 0$ $4 \cdot 8 \times 3 \cdot 2-4 \cdot 0 \mu \mathrm{m}[\mathrm{x}=4 \cdot 3 \pm 0 \cdot 4 \times 3 \cdot 5 \pm 0 \cdot 4 \mu \mathrm{m}, \mathrm{Qm}=1 \cdot 2$, $n=20$ ], subhyaline, pale olivaceous to pale brown. The teleomorph is unknown.

$\mathrm{CP} 141 \mathrm{~b}^{\mathrm{T}}$ is positive for catalase, oxidase and urease activities and negative for lipase, phosphatase, gelatinase, DNase, $\beta$-galactosidase, phenylalanine deaminase and arginine dihydrolase activities, as well as lysine and ornithine decarboxylases. Is not able to hydrolyse casein or aesculin. The fungus is able to utilize acetate, arabinose, fructose, galactose, glucose, glycerol, inulin, lactic acid, lactose, levulose, maltose, mannitol, raffinose, sucrose and xylose as a sole carbon source, but is not able to utilize citrate, dextrin, ethanolamine or succinate. Cells of $\mathrm{CP} 141 \mathrm{~b}^{\mathrm{T}}$ are sensitive to cycloheximide.

Holotype: Colorado Plateau (38 $34^{\prime}$ 09.84" N $109^{\circ} 31^{\prime}$ $04 \cdot 51^{\prime \prime} \mathrm{W}$ ), USA, isolated from a biological soil crust sample. A dried culture of Exophiala crusticola (type strain $\mathrm{CP} 141 \mathrm{~b}^{\mathrm{T}}$ ) is deposited at UAMH (accession no. 10686). The type strain $\mathrm{CP} 141 \mathrm{~b}^{\mathrm{T}}$ is also maintained freeze-dried at the ATCC (ATCC MYA-3639 ${ }^{\mathrm{T}}$ ), CBS (CBS $119970^{\mathrm{T}}$ ) and DSMZ $\left(\right.$ DSM $\left.16793^{\mathrm{T}}\right)$ culture collections.

\section{Acknowledgements}

The research was funded by the National Science Foundation Biotic Surveys and Inventories grant 0206711 (F. G.-P.) We acknowledge support from Garcia-Pichel lab members in the field as well as in the 
lab. Tonya R. Boschmann contributed by reading over the manuscript. Dr L. Sigler kindly offered advice regarding the type specimen. We would also like to acknowledge an anonymous reviewer whose thorough evaluation improved the quality of this publication.

\section{References}

Altschul, S. F., Madden, T. J., Schäffer, A. A., Zhang, J., Zhang, Z., Miller, W. \& Lipman, D. J. (1997). Gapped BLAST and PSI-BLAST: a new generation of protein database search programs. Nucleic Acids Res 25, 3389-3402.

Belnap, J. \& Gardner, J. S. (1993). Soil microstructure in soils of the Colorado Plateau: the role of the cyanobacterium Microcoleus vaginatus. Great Basin Nat 53, 40-47.

Belnap, J., Büdel, B. \& Lange, O. L. (2001). Biological soil crusts: characteristics and distribution. In Biological Soil Crusts: Structure, Function, and Management (Ecological Studies no. 150), pp. 3-30. Edited by J. Belnap \& O. L. Lange. Berlin: Springer.

de Hoog, G. S. (1993). Evolution of black yeasts: possible adaptation to the human host. Antonie van Leeuwenhoek 63, 105-109.

de Hoog, G. S. \& Hermanides-Nijhof, E. J. (1977). Survey of black yeasts and allied Hyphomycetes. Stud Mycol 15, 178-221.

de Hoog, G. S., Vicente, V., Caligiorne, R. B., Kantarcioglu, S., Tintelnot, K., Gerrits van den Ende, A. H. G. \& Haase, G. (2003). Species diversity and polymorphism in the Exophiala spinifera clade containing opportunistic black yeast-like fungi. J Clin Microbiol 41, 4767-4778.

Fletcher, J. E. \& Martin, W. P. (1948). Some effects of algae and molds in the rain-crust of desert soils. Ecology 29, 95-100.

Galun, M. \& Garty, J. (2001). Biological soil crusts of the Middle East. In Biological Soil Crusts: Structure, Function, and Management (Ecological Studies no. 150), pp. 95-106. Edited by J. Belnap \& O. L. Lange. Berlin: Springer.

Garcia-Pichel, F. (2002). Desert environments: biological soil crusts. In Encyclopedia of Environmental Microbiology, pp. 1019-1023. Edited by G. Bitton. New York: Wiley.

Garcia-Pichel, F., López-Cortés, A. \& Nübel, U. (2001). Phylogenetic and morphological diversity of cyanobacteria in soil desert crusts from the Colorado Plateau. Appl Environ Microbiol 67, 1902-1910.

Greuter, W., Mcneill, J., Barrie, F. R. \& 9 other authors (2000). International Code of Botanical Nomenclature (Saint Louis Code). Regnum Vegetabile series, volume 138. Königstein, Germany: Koeltz Scientific Books.

Grishkan, I., Zaady, E. \& Nevo, E. (2006). Soil crust microfungi along a southward rainfall gradient in a desert ecosystems. Eur J Soil Biol 43, 33-42.

Gundlapally, S. R. \& Garcia-Pichel, F. (2006). The community and phylogenetic diversity of biological soil crusts in the Colorado Plateau studied by molecular fingerprinting and intensive cultivation. Microb Ecol 52, 345-357.

Haase, G., Sonntag, L., Melzer-Krick, B. \& de Hoog, G. S. (1999). Phylogenetic inference by SSU-gene analysis of members of the Herpotrichiellaceae with special reference to human pathogenic species. Stud Mycol 43, 80-97.

Kimura, M. (1980). A simple method for estimating evolutionary rates of base substitutions through comparative studies of nucleotide sequences. J Mol Evol 16, 111-120.

Kirk, P. M., Cannon, P. F., David, J. C. \& Stalpers, J. A. (2001). Ainsworth and Bisby's Dictionary of the Fungi, 9th edn. Wallingford: CABI Publishing.
Kornerup, A. \& Wanscher, J. H. (1967). Methuen Handbook of Colour, 2nd edn. London: Methuen.

Kumar, S., Tamura, K. \& Nei, M. (2004). MEGA3: Integrated software for molecular evolutionary genetics analysis and sequence alignment. Brief Bioinform 5, 150-163.

Kurtzman, C. P. \& Robnett, C. J. (1998). Identification and phylogeny of ascomycetous yeasts from analysis of nuclear large subunit (26S) ribosomal DNA partial sequences. Antonie van Leeuwenhoek 73, 331-371.

Lorch, H. J., Benckiser, G. \& Ottow, J. C. G. (1995). Basic methods for counting microorganisms in soil and water. In Methods in Applied Soil Microbiology and Biochemistry, pp. 162-170. Edited by K. Alef \& P. Nannipieri. San Diego: Academic Press.

Müller, E., Petrini, O., Fischer, P. J., Samuels, G. J. \& Rossman, A. Y. (1987). Taxonomy and anamorphs of the Herpotrichiellaceae with notes on generic synonymy. T Brit Mycol Soc 88, 63-74.

Nagy, M., Pérez, A. \& Garcia-Pichel, F. (2005). The prokaryotic diversity of biological soil crusts in the Sonoran desert (Organ Pipe Cactus National Monument, AZ). FEMS Microbiol Ecol 54, 233-245.

O'Donnell, K. (1993). Fusarium and its near relatives. In The Fungal Holomorph: Mitotic, Meiotic and Pleomorphic Speciation in Fungal Systematics, pp. 225-233. Edited by D. R. Reynolds \& J. W. Taylor. Wallingford: CABI Publishing.

Peterson, S. W. \& Kurtzman, C. P. (1991). Ribosomal RNA sequence divergence among sibling species of yeasts. Syst Appl Microbiol 14, 124-129.

Reddy, G. S. N. \& Garcia-Pichel, F. (2005). Dyadobacter crusticola sp. nov., from biological soil crusts in the Colorado Plateau, USA, and an emended description of the genus Dyadobacter Chelius and Triplett 2000. Int J Syst Evol Microbiol 55, 1295-1299.

Reddy, G. S. N., Nagy, M. \& Garcia-Pichel, F. (2006). Belnapia moabensis gen. nov., sp. nov., an alphaproteobacterium from biological soil crusts in the Colorado Plateau, USA. Int J Syst Evol Microbiol 56, 51-58.

Rippka, R., Deruelles, J., Waterbury, J. B., Herdmann, M. \& Stanier, R. Y. (1979). Generic assignment, strain histories and properties of pure cultures of cyanobacteria. J Gen Microbiol 111, 1-16.

Smith, S. M., Abed, R. M. M. \& Garcia-Pichel, F. (2004). Biological soil crusts of sand dunes in Cape Cod National Seashore, Massachusetts, USA. Microb Ecol 48, 200-208.

Spatafora, J. W., Mitchell, T. G. \& Vilgalys, R. (1995). Analysis of genes coding for small-subunit rRNA sequences in studying phylogenetics of dematiaceous fungal pathogens. J Clin Microbiol 33, 1322-1326.

States, J. S. \& Christensen, M. (2001). Fungi associated with biological soil crusts in the desert grasslands of Utah and Wyoming. Mycologia 93, 432-439.

Untereiner, W. A. \& Naveau, F. A. (1999). Molecular systematics of the Herpotrichiellaceae with an assessment of the phylogenetic positions of Exophiala dermatididis and Phialophora americana. Mycologia 91, 67-83.

White, T. J., Bruns, T., Lee, S. \& Taylor, J. W. (1990). Amplification and direct sequencing of fungal ribosomal RNA genes for phylogenetics. In PCR Protocols: a Guide to Methods and Applications, pp. 315-322. Edited by M. A. Innis, D. H. Gelfand, J. J. Sninsky, \& T. J. White. New York: Academic Press.

Yarrow, D. (1998). Methods for the isolation, maintenance and identification of yeasts. In The Yeasts, a Taxonomic Study, 4th edn, pp. 77-100. Edited by C. P. Kurtzman \& J. W. Fell. Amsterdam: Elsevier. 